\title{
POSISI, TANTANGAN, DAN PROSPEK BAGI INDONESIA DALAM SISTEM PENYELESAIAN SENGKETA WTO
}

\author{
Dyan F. D. Sitanggang \\ e-mail: dyanfranciska@unpar.ac.id
}

\begin{abstract}
The World Trade Organization (WTO) as the sole universal organization managing global trade between member-states has develop a dispute settlement mechanism to deal with disagreement related to the interpretation and/or implementation of reciprocal rights and duties in the economic field. However, the effectiveness of this system hinges on compliance of states to decisions reached. Compliance in its turn are influenced by how parties to a dispute value the justness or equity of the final settlement. This paper discusses WTO Dispute Settlement Understanding (DSU) and how Indonesia perceived and utilizes this forum to further its national interest.
\end{abstract}

Keywords:

WTO, DSU, compliance issue

\begin{abstract}
Abstrak
World Trade Organization (WTO) sebagai satu-satunya organisasi yang mengatur perdagangan antarnegara telah menyediakan mekanisme penyelesaian sengketa secara damai yang menyeluruh. Namun, sistem penyelesaian sengketa hanya efektif bila dipatuhi, dan semua negara diperlakukan secara adil baik negara-negara maju, berkembang, atau yang kurang berkembang. Dalam tulisan ini diteliti sistem penyelesaian sengketa WTO dalam Dispute Settlement Understanding (DSU) dan prakteknya oleh Indonesia dalam beberapa kasus. Akan ditelaah bagaimana Indonesia sebagai Negara berkembang ketika bersengketa di hadapan DSU dapat memperkuat posisi hukumnya.
\end{abstract}

Kata kunci:

WTO, DSU, isu kepatuhan

\section{Pendahuluan}

Pentingnya ekonomi bagi negara bukan hanya karena dampaknya bagi masyarakat, tetapi juga kepentingan berbagai aktor di dalamnya. Di dalam sistem ekonomi internasional, negara-negara diakomodasi World Trade Organization (WTO), satu-satunya badan internasional yang mengatur perdagangan antarnegara. WTO didirikan tahun 1995 dari proses negosiasi Uruguay Round tahun 1986-1994 serta rangkaian perundingan General Agreement on Tariffs and Trade (GATT) sejak 1948. WTO disebut pencapaian terbaik dalam institusionalisasi kerjasama ekonomi global, ${ }^{1}$ dibentuk untuk mengimplementasi perjanjian-perjanjian dagang, sebagai forum negosiasi perdagangan, menangani

\footnotetext{
1 G. Sampson (ed.), The Role of the World Trade Organization in Global Governance, United Nations University Press, Tokyo, 2001, hlm., 5.
} 
sengketa perdagangan, mengawasi kebijakan perdagangan nasional, memberi bantuan teknis dan pelatihan bagi negara-negara berkembang serta kerjasama dengan organisasi internasional lain. Indonesia telah menjadi anggota sejak 1 Januari 1995, sebelumnya anggota GATT sejak 24 Februari 1950, dan meratifikasi Persetujuan WTO dengan Undang-Undang Nomor 7 Tahun 1994 tentang Pengesahan Agreement Establishing the World Trade Organization.

Mengingat pentingnya perdagangan terhadap kepentingan negara, tidaklah mengejutkan ketika negara-negara anggota WTO tidak selalu sepaham mengenai interpretasi serta aplikasi peraturan-peraturan tersebut. ${ }^{2}$ Meski telah ada peraturan-peraturan hukum dalam hal kerjasama ekonomi internasional, konflik kepentingan dan ketidaksepahaman yang berlanjut menjadi sengketa antar negara tidak dapat dihindari. Dengan didasari prinsip penyelesaian sengketa secara damai, negara-negara diharapkan menggunakan di antara dua metode yang tersedia untuk menyelesaikan sengketa, yaitu perundingan atau negosiasi diplomatik antara negara-negara yang bersengketa (dengan tingkatan intervensi dan bantuan negara ketiga yang beragam), dan sistem pengadilan oleh entitas yang independen (melalui arbitrase dan penyelesaian di jalur hukum). ${ }^{3}$

WTO menyediakan sistem penyelesaian sengketa antara negara-negara anggota mengenai hak dan kewajiban mereka di bawah persetujuan-persetujuan WTO. Sistem penyelesaian sengketa WTO sudah beroperasi selama dua puluh dua tahun sejak 1 Januari 1995. Sampai saat ini, sejumlah 524 sengketa telah dibawa kepada sistem penyelesaian sengketa WTO. ${ }^{4}$ Seperempat dari kasus-kasus tersebut terselesaikan melalui konsultasi, atau tanpa diajukan ke jalur hukum. Pada sengketa-sengketa lain, para pihak merujuk kepada pengadilan. Mekanisme ini bisa dikatakan sebagai tulang punggung dari rezim perdagangan multilateral saat ini demi menciptakan suatu sistem yang kuat dan mengikat semua pihak, dan

\footnotetext{
2 Peter Van den Bossche, The Law and Policy of the World Trade Organization: Text, Cases and Materials, Cambridge University Press, Cambridge, 2005, hlm., 173.

3 Peter Malanczuk, Akehurst's Modern Introduction to International Law, Seventh Revised Edition, Routledge, New York, 1997, hlm., 273.

4 WTO, Current Status of Disputes, https://www.wto.org/english/tratop_e/dispu_e/dispu_current_status_e.htm, diakses pada 4 April 2017.
} 
agar para negara anggota dapat mematuhi peraturan-peraturan yang telah disepakati bersama dalam persetujuan-persetujuan WTO. Mekanisme ini disusun dalam Dispute Settlement Understanding (DSU) sebagai pembaharuan sistem yang disediakan di dalam GATT sebelumnya, demi kestabilan perekonomian global. ${ }^{5}$

Berdasarkan laporan WTO tahun 2015,6 Indonesia telah terlibat dalam beberapa sengketa yang telah sampai pada laporan final Panel dan Appellate Body yang diadopsi DSB. Dalam tulisan ini, yang akan dibahas adalah Offset Act dimana Indonesia menjadi salah satu complainant terhadap Amerika Serikat terkait US Continued Dumping and Subsidy Act tahun 2000, Autos dimana Indonesia menjadi respondent terhadap komplain yang diajukan oleh Uni Eropa, Jepang dan Amerika Serikat atas Program Mobil Nasional 1996 yang dibuat Indonesia, Certain Paper dimana Indonesia menjadi complainant mewakili perusahaan-perusahaan nasional terhadap Korea Selatan dalam kasus tuduhan dumping produk kertas, Clove Cigarettes dimana Indonesia mengajukan komplain terhadap Amerika Serikat dalam kasus produk rokok kretek Indonesia di Amerika Serikat. Ada pula sejumlah kasus baik Indonesia sebagai complainant atau respondent yang masih dalam tahap konsultasi, persetujuan pembentukan Panel, dan tahap lainnya, juga kasus-kasus dimana Indonesia merupakan pihak ketiga.

Dalam tulisan ini akan dibahas pelaksanaan penyelesaian sengketa dalam kerangka WTO ketika melibatkan Indonesia, mengingat dalam kasus-kasus dimana Indonesia terlibat sebagai complainant atau respondent, Indonesia sering berhadapan dengan negara maju. Dengan menganalisis proses penyelesaian sengketa tersebut melalui empat kasus aktual dan mengetahui posisi dan tantangan yang dihadapi Indonesia, tujuan tulisan ini adalah agar dapat diidentifikasi langkah-langkah yang bisa ditempuh Indonesia untuk memperkuat posisinya, dengan harapan agar kepentingan nasional Indonesia dalam perdagangan internasional tidak diciderai meski harus diperhadapkan dengan negara-negara maju.

\footnotetext{
5 Freddy Josep Pelawi, Penyelesaian Sengketa WTO dan Indonesia, Direktorat Jenderal Kerjasama Perdagangan Internasional, Buletin KPI Edisi 44, 2007.

6 World Trade Organization, WTO Dispute Settlement: One Page Case-Summaries 1995-2014 , 2015.
} 


\section{Tinjauan Umum Penyelesaian Sengketa WTO dalam DSU}

WTO memiliki dua peran, peran legislatif sebagai organisasi internasional yang di dalamnya persetujuan-persetujuan ditandatangani dan peran ajudikasi. Peran legislatif dibatasi pada tindakan dalam hubungan perdagangan antar negara anggota dan peran ajudikasi untuk konsultasi dan mengadili permasalahan antara negara anggota terkait peraturan dalam persetujuan di lingkup WT0.7 ${ }^{7}$ Sistem penyelesaian sengketa WTO sering dipuji sebagai salah satu inovasi paling penting dari Uruguay Round ${ }^{8}$ dan dalam proses perkembangan penyelesaian sengketa internasional secara keseluruhan. Meskipun perdagangan dalam WTO dipahami sebagai aliran barang dan jasa antara negara anggota, perdagangan tersebut tidak dilakukan oleh negara, tetapi oleh operator ekonomi privat di dalam negara, dan peserta pasar ini membutuhkan stabilitas dan prediktabilitas dalam hukum, kepastian, peraturan, dan regulasi yang mencakup aktivitas komersil, khususnya saat mengadakan perdagangan dengan basis transaksi jangka panjang. Maka, DSU menyediakan sistem penyelesaian sengketa yang cepat, efisien, dapat diandalkan dan berorientasi pada peraturan mengenai aplikasi persetujuan-persetujuan WTO.

Saat terjadi ketidakpatuhan persetujuan-persetujuan WTO oleh anggota WTO, sistem menyediakan resolusi yang secara relatif cepat melalui pengadilan independen yang harus dilaksanakan segera, atau anggota yang tidak mengimplementasikan akan diberi sanksi perdagangan. Selain itu, tujuan sistem ini adalah agar anggota-anggota menyelesaikan sengketa melalui prosedur multilateral dan bukan tindakan unilateral. Setiap proses penyelesaian sengketa harus diawali konsultasi atau usaha untuk memulai konsultasi antara para pihak yang bersengketa, untuk mencapai solusi yang disepakati bersama. Solusi yang dicapai melalui negosiasi harus konsisten dengan hukum WTO. Penyelesaian sengketa tidak hanya untuk melindungi hak dan kewajiban anggota dalam persetujuan terkait, tetapi juga mengklarifikasi peraturan-peraturan dalam

7 WTO Agreement, Article II; Understanding on Rules and Procedures Governing the Settlement of Disputes, 1994, 1869 U.N.T.S. 401, art. 1.1. [selanjutnya disebut DSU]

8 World Trade Organization, A Handbook on the WTO Dispute Settlement System, Cambridge University Press, Cambridge, 2004, hlm., 12. [selanjutnya disebut WTO Handbook] 
persetujuan tersebut. Namun rekomendasi dan keputusan Dispute Settlement Body (DSB) tidak bisa menambah atau mengurangi hak dan kewajiban yang sudah diatur. Penggunaan prosedur penyelesaian sengketa tidak boleh bertujuan atau dianggap sebagai tindakan perbantahan, dan semua anggota harus terlibat dalam prosedur ini dengan itikad baik untuk menyelesaikan sengketa.

Metode penyelesaian sengketa dalam DSU, yaitu: konsultasi atau negosiasi, pengadilan oleh Panel dan Appellate Body, arbitrase, dan jasa baik, konsiliasi dan mediasi. Jasa baik, konsiliasi atau mediasi, yang dapat dimintakan kapan saja, dan dapat dimulai serta diakhiri kapan pun dan dapat berlanjut sementara proses Panel berlangsung. Sistem ini juga menyediakan jalur arbitrase sebagai metode alternatif. Pemulihan pelanggaran hukum WTO dalam DSU sendiri pemulihan final, yaitu penarikan atau perubahan peraturan yang tidak sesuai dengan WTO; dan pemulihan sementara dan dapat dipakai ketika menunggu penarikan atau perubahan peraturan yang tidak sesuai tersebut, yakni kompensasi dan penangguhan konsesi atau kewajiban-kewajiban lainnya (retaliasi).

Sistem penyelesaian sengketa WTO bersifat integral maka yurisdiksinya termasuk semua sengketa antara anggota WTO yang timbul dari persetujuan yang masuk cakupan WTO, termasuk di dalamnya Persetujuan WTO, GATT 1994 dan semua persetujuan multilateral dalam perdagangan barang, GATS, TRIPS Agreement dan DSU. Negara-negara anggota dilarang menentukan adanya satu tindakan pelanggaran selain melalui sistem penyelesaian sengketa dalam DSU. Yurisdiksi sistem ini sifatnya memaksa dan bukan nasihat sehingga wajib dilaksanakan. Aksesnya dibatasi bagi negara anggota WTO saja, baik sebagai pihak yang bersengketa ataupun pihak ketiga. Sistem penyelesaian sengketa WTO adalah sistem penyelesaian sengketa pemerintah-terhadap-pemerintah untuk sengketa terkait hak-hak dan kewajiban-kewajiban anggota WTO, sehingga Sekretariat WTO, observer WTO, organisasi internasional, pemerintahan regional atau lokal tidak bisa menginisiasi persidangan penyelesaian sengketa di WTO.

Ada beberapa kasus yang dibawa kepada WTO adalah sengketa dari pemerintah atas pengaruh dari industri atau perusahaan. Sistem hukum dari beberapa anggota WTO secara eksplisit menyediakan kemungkinan bagi asosiasi- 
asosiasi industri dan/atau perusahaan-perusahaan untuk membawa pelanggaran kewajiban WTO oleh anggota WTO yang lain untuk diperhatikan oleh pemerintahnya dan 'mempengaruhi' pemerintahnya untuk memulai proses penyelesaian sengketa WTO melawan anggota tersebut. Asosiasi industri dan perusahaan individual memiliki akses tidak langsung kepada sistem ini. ${ }^{9}$

Proses penyelesaian sengketa diikuti oleh para pihak dan pihak ketiga, Dispute Settlement Body (DSB), Panel, Appellate Body (tingkat banding), Sekretariat WTO, para Arbitrator, ahli-ahli independen dan beberapa institusiinstitusi khusus. Empat langkah utama proses penyelesaian sengketa WTO, yakni konsultasi, persidangan Panel, persidangan review untuk banding, implementasi dan pelaksanaan. Salah satu yang menarik perhatian dari sistem penyelesaian sengketa WTO adalah kurun waktu yang singkat untuk proses persidangan baik Panel maupun Appelate Body. Kurun waktu konsultasi dan implementasi juga diatur ketat. Prinsipnya, persidangan Panel tidak boleh lebih dari sembilan bulan, namun pada prakteknya sering melampaui batas waktu yang ditentukan, hingga rata-rata proses Panel berlangsung selama kurang-lebih dua belas bulan. Hal ini disebabkan antara lain kerumitan kasus, dibutuhkan konsultasi dengan ahli, masalah penjadwalan, dan lain-lain. Sedangkan persidangan Appellate Body tidak diperbolehkan lebih dari sembilan puluh hari.

Dalam prosedur penyelesaian sengketa WTO, negara berkembang diberi perlakuan khusus. Pasal 4.10 DSU meminta agar fokus diberikan kepada situasisituasi tertentu yang melibatkan negara berkembang dalam konsultasi, dan Pasal 12.10 mengizinkan penambahan waktu konsultasi jika disetujui para pihak. Dalam kasus India - Quantantive Restrictions tahun 1995 India meminta penambahan waktu kepada Panel dalam mempersiapkan submisi tertulis pertamanya. Pasal 8.19 DSU juga menyatakan bahwa jika negara berkembang terlibat suatu sengketa, dapat meminta Panel terdiri setidak-tidaknya satu orang dari negara berkembang. Dalam Pasal 12.11, laporan Panel harus mempertimbangkan keadaan negara berkembang terkait differential and more favorable treatment, dan dalam Pasal

9 Supra no 2, hlm., 202-203. 
21.8 dalam memutus DSB harus mempertimbangkan tidak hanya segi perdagangan tetapi juga dampaknya bagi sistem ekonomi negara tersebut. WTO pun dapat memberikan bantuan teknis kepada negara berkembang di Pasal 27.2 dalam bentuk nasihat hukum. Dalam Pasal 24.1 tercantum penahanan penggunaan DSU terhadap least-developed countries terkait kompensasi dan aplikasi penangguhan konsesi serta kewajiban lainnya.

\section{Keterlibatan Indonesia Dalam Sistem Penyelesaian Sengketa WTO}

\section{A. Indonesia - Autos ${ }^{10}$}

Indonesia menjadi respondent atau tergugat dalam kasus ini, dan bisa disebut sebagai keterlibatan Indonesia dalam sengketa di WTO yang paling sering dibahas, terkait Paket Kebijakan Otomotif 1993 yang memberikan pengurangan atau pembebasan bea impor/bea masuk bagi komponen otomotif berdasarkan persentase konten lokal, dan Program Mobil Nasional 1996 yang memberikan beragam keuntungan seperti pembebasan pajak barang mewah atau pembebasan bea masuk untuk mobil-mobil tertentu dengan konten lokal misalnya, atau perusahaan-perusahaan mobil Indonesia. Produsen mobil diperbolehkan memilih kebijakan sendiri atas komponen mana yang akan menggunakan konten lokal dan akan mendapatkan potongan bea masuk atau bahkan dibebaskan dari bea masuk jika berhasil mencapai tingkat kandungan komponen lokal tertentu.

Program Mobil Nasional tahun 1996 awalnya merupakan inisiatif Indonesia untuk memajukan industri mobil nasional. Bedasarkan Inpres Nomor 2 Tahun 1996 tentang Program Mobil Nasional, PT Timor Putra Nasional ditunjuk sebagai perusahaan yang memproduksi mobil nasional. Dikarenakan keterbatasan infrastruktur dan kelengkapan produksi dalam negeri, dikeluarkan Keppres Nomor 42 Tahun 1996 yang memberikan izin bagi PT Timor Putra Nasional mengimpor mobil dari Korea Selatan dalam bentuk jadi yang diberi merek 'Timor', yang lalu menerima reaksi negatif dari Jepang, Amerika Serikat dan beberapa negara Eropa.

10 Panel Report, Indonesia - Certain Measures Affecting the Automobile Industry, WT/DS54/R, WT/DS55/R, WT/DS59/R, WT/DS64/R and Corr.1 and Corr.2, adopted 23 July 1998, and Corr.3 and Corr.4, DSR 1998:VI, hlm. 2201. 
Sesuai prosedur DSU, Uni Eropa meminta konsultasi dengan Indonesia pada 3 Oktober 1996, diikuti Jepang pada 4 Oktober 1996 dan 29 November 1996, dan Amerika Serikat pada 8 Oktober 1996. Uni Eropa menyatakan bahwa Indonesia telah melanggar kewajiban dalam Pasal I dan III GATT 1994, Pasal 2 Agreement on Trade-Related Investment Measures (TRIMs) dan Pasal 3 Agreement on Subsidies and Countervailing Measures (SCM). Jepang menyatakan bahwa peraturan Indonesia bertentangan dengan Pasal I:1, III:2, III:4 dan X:3(a) GATT 1994, Pasal 2 dan 5.4 TRIMs. Sementara Amerika Serikat menyatakan bahwa Indonesia melanggar Pasal I dan III GATT 1994, Pasal 2 TRIMs, Pasal 3, 6 dan 8 SCM, dan Pasal 3, 20 dan 65 Agreement on Trade-Related Aspect of Intellectual Property Rights (TRIPS).

Pada 17 April 1997, Jepang memohon pembentukan Panel, diikuti Uni Eropa 12 Mei 1997. DSB menangguhkan pembentukan Panel tanggal 23 Mei 1997. Jepang dan Uni Eropa kemudian mengajukan permohonan kedua untuk pembentukan Panel yang akhirnya dibentuk tanggal 12 Juni 1997. Sesuai DSU, diputuskan bahwa Panel tunggal akan mengadili kasus tersebut. India, Korea Selatan dan Amerika Serikat mendapat hak pihak ketiga. Di tanggal yang sama, Amerika Serikat juga memohon pembentukan Panel yang ditangguhkan DSB tanggal 25 Juni 1997. Permohonan kedua diajukan oleh Amerika Serikat, dan DSB membentuk Panel tanggal 30 Juli 1997, namun disatukan dengan Panel yang mengadili kasus serupa yang dibawa Jepang dan Uni Eropa. India dan Korea Selatan mendapat hak pihak ketiga. Uni Eropa dan Jepang meminta DirekturJenderal WTO untuk menentukan komposisi Panel dan pada 29 Juli 1997 Panel resmi terbentuk.

Panel melaporkan bahwa Indonesia melanggar Pasal I dan II:2 GATT 1994, Pasal 2 TRIMs dan Pasal 5(c) SCM. Indonesia dinyatakan melanggar kewajiban national treatment dengan inisiasi konten lokal, melanggar kewajiban mostfavoured nation dengan hanya menggunakan produk dari Korea Selatan, dan menyebabkan kerugian produk sejenis dari Eropa. Laporan ini diedarkan pada tanggal 2 Juli 1998 dan diadopsi DSB pada 23 Juli 1998. Indonesia tidak mengajukan banding dan menunjukkan niat untuk menaati rekomendasi DSB 
dalam waktu sesuai Pasal 21 DSU. Rekomendasi dan keputusan DSB, yaitu Indonesia harus menanggulangi akibat yang ditimbulkan, menarik subsidi, dan harus menyesuaikan seluruh peraturan dan kebijakan dengan prinsip perdagangan internasional yang ada dalam persetujuan-persetujuan WTO.

Uni Eropa membawa kasus kepada arbitrase untuk menentukan batas waktu yang diberikan kepada Indonesia, dan ditetapkan waktu implementasi rekomendasi dan keputusan DSB 12 bulan sejak adopsi laporan Panel, tenggat waktu hingga 23 Juli 1999 berdasarkan pertimbangan Indonesia sebagai negara berkembang. Hasil arbitrase diedarkan kepada negara anggota pada 7 Desember 1998. Tanggal 15 Juli 1999, Indonesia menginformasikan DSB bahwa kebijakan otomotif baru telah dikeluarkan tanggal 24 Juni 1999 (Kebijakan Otomotif 1999) yang secara efektif mengimplementasikan rekomendasi dan keputusan DSB.

Semenjak diajukannya gugatan oleh Jepang, Uni Eropa dan Amerika Serikat, pemerintah Indonesia berkali-kali mengusahakan negosiasi, salah satunya ketika pemerintah Indonesia mendiskusikan dengan Jepang pada pertemuan bilateral keduanya. Namun, Indonesia tetap mempertahankan program mobil nasional untuk memajukan industri otomotif negara. Begitu pula sampai proses Panel. Ketika keputusan diadopsi DSB, Indonesia belum langsung mengimplementasikannya. Langkah yang dilakukan Indonesia adalah mengeluarkan Surat Keputusan Kementerian Keuangan Nomor 205/MK.03/1998 yang berisi fasilitas kredit untuk pembelian kendaraan bermotor bagi anggota Dewan Perwakilan Rakyat, diakibatkan stok mobil Timor yang belum terjual. Atas desakan WTO dan International Monetary Fund, fasilitas tersebut dicabut dan mobil Timor mengalami krisis pemasaran karena harga yang naik drastis dan onderdil mobil tersebut yang tidak beredar di Indonesia karena tergantung pada produsen di Korea Selatan. 


\section{B. US - Offset Act ${ }^{11}$}

Dalam kasus ini, Indonesia bersama negara-negara lain, yaitu Australia, Brazil, Chili, Uni Eropa, India, Jepang, Korea Selatan, Thailand, Kanada dan Meksiko menggugat Amerika Serikat untuk undang-undang US Continued Dumping and Subsidi Act 2000. Tuntutan ini isinya menyebut undang-undang tersebut melanggar ketentuan WTO dalam Anti-Dumping Agreement, SCM, dan Persetujuan WTO. Undang-Undang yang dipersengketakan berisi peraturan yang membagikan bea anti-dumping dan countervailing yang dikumpulkan pemerintah Amerika Serikat kepada industri domestiknya yang dirugikan oleh tindakan dumping atau subsidi negara lain dianggap oleh negara-negara yang melakukan kegiatan ekspor produk ke pasar Amerika Serikat sebagai kebijakan yang dapat digunakan secara berlebihan oleh industri domestik Amerika Serikat untuk mengklaim kerugian berat atas masuknya barang impor yang berharga murah dan menuduh barang impor murah tersebut akibat tindakan dumping yang dilakukan pengusaha pengekspor atau subsidi yang dilakukan negara lain kepada perusahaan eksportirnya. Inti kasus ini adalah pengusaha domestik dapat meminta perlindungan berlebih kepada Amerika Serikat, sehingga merugikan pengusaha-pengusaha negara lain yang mengekspor produk di pasar Amerika Serikat.

Kasus ini terjadi dalam kurun waktu sejak tahun 2000 diajukan gugatan sampai tahun 2006 akhirnya Amerika Serikat melakukan revisi Undang-Undang. Tahun 2002, Panel mengeluarkan laporan yang menyatakan bahwa UndangUndang tersebut melanggar ketentuan dalam WTO dan memberi rekomendasi untuk membatalkannya, tetapi tidak dipatuhi Amerika Serikat yang kemudian pada tahun yang sama mengajukan banding. Appellate Body pun mengeluarkan keputusan yang kurang lebih sama, memperkuat laporan Panel dan merekomendasikan hal yang sama untuk Amerika Serikat. Laporan Panel dan Appellate Body kemudian diadopsi DSB pada tahun 2003. Para penggugat

\footnotetext{
${ }^{11}$ Panel Report, United States - Continued Dumping and Subsidy Offset Act of 2000, WT/DS217/R, WT/DS234/R, adopted 27 January 2003, as modified by Appellate Body Report WT/DS217/AB/R, WT/DS234/AB/R, DSR 2003:II, hlm., 489.
} 
berdasarkan Pasal 21.3(c) DSU mengajukan permintaan untuk arbitrase karena rekomendasi tersebut tidak dilaksanakan Amerika Serikat dan arbiter menyatakan bahwa batas waktu yang wajar untuk melaksanakan rekomendasi DSB adalah 11 bulan sejak tanggal adopsi DSB tentang laporan Panel dan Appelate Body, yakni 27 Desember 2003.

Amerika Serikat lalu membuat kesepakatan bersama Thailand, Australia dan Indonesia untuk mengubah jangka waktu menjadi tanggal 27 Desember 2004 dan melaporkannya kepada DSB. Tanggal 14 Januari 2004, Brazil, Chili, Uni Eropa, India, Jepang, Korea Selatan dan Kanada meminta otorisasi DSB untuk menangguhkan konsesi. Amerika Serikat mengajukan keberatan penangguhan dan meminta rujuk masalah ke arbitrase. DSB menyerahkan masalah tersebut kepada arbitrase yang memutus menolak posisi complainant terkait penangguhan konsesi, dan arbitrase menyatakan bahwa penangguhan konsesi atau kewajiban lainnya harus dilakukan sesuai nilai kerugian yang diperhitungkan arbiter. 23 Desember 2004 dan 7, 11 Januari 2005 kembali dibuat kesepakatan Amerika Serikat dengan Australia, Thailand dan Indonesia lalu dilaporkan kepada DSB. Pada pertemuan DSB tanggal 17 Februari 2006, Amerika Serikat menyatakan bahwa Kongres telah menyetujui pencabutan US Continued Dumping and Subsidi Act 2000 dan menerima Deficit Reduction Act pada tanggal 1 Februari 2006 yang telah ditandatangani tanggal 8 Februari 2006 Presiden untuk berlaku, sesuai dengan kewajiban Amerika Serikat dalam WTO.

\section{Korea - Certain Paper ${ }^{12}$}

Dalam kasus ini, Indonesia membawa kepentingan perusahaan-perusahaan nasional melawan Korea Selatan di dalam sistem penyelesaian sengketa WTO, dan Indonesia merupakan penggugat utama. Pada 4 Juni 2004, Indonesia mengajukan konsultasi dengan Korea Selatan terkait tindakan anti-dumping yang dilakukan Korea Selatan terhadap impor kertas dari Indonesia. Korea Selatan menuduh

12 Panel Report, Korea - AntiDumping Duties on Imports of Certain Paper from Indonesia, WT/DS312/R, adopted 28 November 2005, DSR 2005:XXII, hlm. 10637; Panel Report, KoreaAntiDumping Duties on Imports of Certain Paper from Indonesia - Recourse to Article 21.5 of the DSU by Indonesia, WT/DS312/RW, adopted 22 October 2007, DSR 2007:VIII, hlm., 3369. 
Indonesia atas tindakan dumping kertas yang di ekspor ke Korea Selatan, mengakibatkan produsen Indonesia harus membayar bea masuk lebih besar, sebagai hukuman dari Korea Selatan atas dampak tuduhan tersebut. Petisi dumping telah diajukan sejumlah industri kertas di Korea sejak 2002 terhadap PT Indah Kiat Pulp and Paper Tbk, PT Pindo Deli Pulp Mills, PT Pabrik Kertas Tjiwi Kimia Tbk, dan April Pine Paper Trading Pte Ltd., lalu berakhir dengan hukuman bea masuk anti-dumping untuk kertas Indonesia yang diekspor ke Korea sebesar 2,8-8,22 persen. ${ }^{13}$

Konsultasi gagal mencapai kesepakatan, dan Indonesia mengajukan permohonan pembentukan Panel tanggal 16 Agustus 2004 dan ditangguhkan DSB tanggal 31 Agustus 2004. Indonesia kembali mengajukan permohonan pembentukan Panel yang akhirnya dibentuk tanggal 27 September 2004. Kanada, China, Uni Eropa, Jepang dan Amerika Serikat mendapat hak pihak ketiga. Indonesia meminta Direktur-Jenderal WTO untuk membentuk komposisi Panel dan tanggal 25 Oktober 2004, Panel dibentuk. Dalam proses Panel, tanggal 25 April 2005, Chairman Panel melaporkan kepada DSB bahwa tidak memungkinkan untuk menyelesaikan tugasnya dalam kurun waktu enam bulan karena konflik dalam penjadwalan, dan tugasnya diharapkan selesai pada Juli 2005. Laporan Panel diedarkan pada negara anggota tanggal 28 Oktober 2005, menyatakan bahwa Korean Trade Commission (KTC) bertindak tidak konsisten dengan ketentuan anti-dumping dalam menentukan batas dumping perusahaan Indonesia, tidak konsisten dengan pasal-pasal perjanjian yang relevan, menolak data penjualan domestik yang diajukan oleh kedua perusahaan Indonesia, dan aplikasi judicial economy oleh Panel mengenai klaim konsekuensial yang dibawa Indonesia.

Tidak semua klaim yang diajukan Indonesia diproses Panel, tetapi inti dari klaim yaitu Korea Selatan telah melakukan kesalahan dalam pembuktian adanya praktek dumping terhadap produk kertas Indonesia disetujui Panel. Pada 28

\footnotetext{
13 Tempo, Penghentian Kasus Dumping Kertas Belum Direspons Pengusaha Korea, http://bisnis.tempo.co/read/news/2010/10/25/090286990/penghentian-kasus-dumpingkertas-belum-direspons-pengusaha-korea, diakses pada 4 April 2017.
} 
November 2005, DSB mengadopsi laporan tersebut. Pada pertemuan DSB tanggal 20 Desember 2005, Korea Selatan memohon waktu untuk mengimplementasikan rekomendasi dan keputusan DSB dan siap untuk membahasnya dengan Indonesia. Pada 10 Februari 2006, para pihak melaporkan kepada DSB kesepakatan tenggat waktu implementasi selama 8 bulan hingga 28 Juli 2006.

Pada 17 Agustus 2006, Korea Selatan dan Indonesia melapor pada DSB terkait prosedur dalam Pasal 21 dan 22 DSU. Indonesia mengajukan konsultasi tanggal 26 Oktober 2006 dan tanggal 22 Desember 2006, Indonesia meminta pembentukan Panel Compliance sesuai Pasal 21.5, yaitu ketika terjadi sengketa akibat ketidaksepahaman langkah-langkah kepatuhan terhadap rekomendasi dan keputusan DSB, dapat diadakan persidangan dan menggunakan Panel sebelumnya. Tanggal 23 Januari 2007 disetujui, dan China, Uni Eropa, Jepang dan Amerika Serikat mendapat hak pihak ketiga, diikuti Taipei. Pada 2 April 2007, Ketua Panel kembali menginformasikan DSB bahwa Panel tidak bisa menyelesaikan tugas dalam 90 hari karena konflik jadwal, dan diharapkan selesai pada Juni 2007.

Laporan Panel berdasar Pasal 21.5 DSU berikutnya diedarkan kepada negara-negara anggota pada 28 September 2007, yang menyatakan bahwa tindakan KTC tidak sesuai dengan Pasal 6.8 Anti-Dumping Agreement dan paragraf 7 Annex II, KTC bertindak tidak konsisten dengan kewajibannya dalam Pasal 6.2 Anti-Dumping Agreement dengan menolak memberikan kesempatan kepada Sinar Mas Group untuk memberi tanggapan terkait evaluasi faktor kerugian dalam Pasal 3.4, Indonesia gagal memberikan bukti yang cukup sesuai beban pembuktian yang dimiliki sebagai complainant atas klaim sesuai Pasal 6.4, 6.5 dan 6.9 Anti-Dumping Agreement mengenai dugaan pelanggaran KTC atas injury redetermination, dan Indonesia pun gagal membuktikan kesalahan informasi baru KTC dari industri Korea. Semuanya diadopsi DSB pada 22 Oktober 2007. Kasus ini dimenangkan Indonesia. ${ }^{14}$ Korea Selatan dinyatakan melakukan kesalahan dalam membuktikan

\footnotetext{
14 Tempo, Indonesia Menangkan Sengketa Melawan Korea di WTO, http://bisnis.tempo.co/read/news/2005/10/31/05668752/Indonesia-Menangkan-SengketaMelawan-Korea-di-WTO, diakses pada 4 April 2017.
} 
kerugian dan penghitungan marjin dumping. Panel memberi rekomendasi dan keputusan bagi Korea Selatan untuk merevisi aturannya dan melakukan perhitungan kembali bea masuk anti-dumping yang dikenakan kepada perusahaan kertas asal Indonesia.

\section{US - Clove Cigarettes ${ }^{15}$}

Kasus ini muncul karena adanya Family Smoking Prevention and Tobacco Control Act 2009. Amerika Serikat melarang rokok beraroma untuk diproduksi dan diedarkan. Pada tahap awal penyelesaian sengketa ini, Indonesia sudah melakukan konsultasi pada 7 Maret 2010 untuk mencari solusi bersama atas Undang-Undang tersebut. Pada 13 Mei 2010, Indonesia dan Amerika Serikat juga telah melakukan konsultasi formal dalam kerangka DSB WTO. Namun konsultasi tidak berujung pada kesepakatan dan tidak ada respon maupun itikad baik dari Amerika Serikat untuk menyelesaikan kasus ini. Pemerintah Indonesia sudah melakukan lobi bahkan sejak Rancangan Undang-Undangnya masih dibahas di Kongres, namun tidak didapati solusi. Pada 22 Juni 2010 Indonesia mengajukan pembentukan Panel ke DSB dengan dasar Amerika Serikat melanggar ketentuan WTO dalam hal national treatment obligation dalam Pasal 2.1 dan 2.2 Technical Barrier to Trade Agreement (TBTA) dan Pasal III GATT 1994, serta penggunaan Pasal XX GATT 1994 yang tidak disertai bukti ilmiah. Indonesia keberatan atas peraturan hukum yang memperlakukan tindakan diskriminatif terhadap rokok kretek yang di ekspor ke Amerika Serikat. Permintaan pembentukan Panel diajukan pada 9 Juni 2010, dibentuk pada 20 Juli 2010 dan komposisinya disetujui pada 9 September 2010. Brazil, Uni Eropa, Guatemala, Norwegia, Turki, Kolumbia, Republik Dominika dan Meksiko menjadi pihak ketiga.

Tanggal 2 September 2011, laporan Panel diedarkan kepada para negara anggota. Panel menyatakan telah terjadi pelanggaran Pasal 2.1 TBTA yang menetapkan prinsip non-diskriminasi, bahwa kebijakan Amerika Serikat tersebut tidak sesuai dengan ketentuan WTO karena rokok kretek dan rokok mentol adalah

15 Panel Report, United States - Measures Affecting the Production and Sale of Clove Cigarettes, WT/DS406/R, adopted 24 April 2012, as modified by Appellate Body Report WT/DS406/AB/R, DSR 2012: XI, hlm., 5865. 
produk sejenis dan keduanya memiliki daya tarik yang sama bagi kaum muda. Indonesia adalah produsen rokok kretek terbesar di dunia dan sebagian besar produk rokok kretek yang dilarang adalah dari Indonesia. Dalam WTO, kebijakan yang membedakan perlakuan terhadap dua produk sejenis merupakan tindakan yang tidak adil. Produk domestik dan produk dari luar negeri yang diekspor harus dilakukan secara sama dan adil. Namun klaim Indonesia bahwa tindakan larangan tersebut tidak diperlukan, atas dasar Pasal 2.2 TBTA, tidak diterima Panel karena Indonesia tidak membawa bukti yang cukup bahwa pelarangan rokok kretek oleh Amerika Serikat bersifat menghambat perdagangan. Panel mencatat bahwa peraturan larangan penjualan rokok kretek adalah salah satu dari langkah yang telah direkomendasikan dalam Framework Convention on Tobacco Control dalam Partial Guidelines oleh World Health Organization. ${ }^{16}$

Pada 15 September 2011, Indonesia dan Amerika Serikat meminta DSB mengadopsi draft keputusan memperpanjang periode 60 hari sesuai Pasal 16.4 DSU terkait banding, hingga 20 Januari 2012. DSB menyetujui dan menyatakan akan mengadopsi laporan Panel tidak lebih dari 20 Januari 2012, terkecuali DSB memutuskan secara konsensus untuk tidak melakukannya atau Indonesia atau Amerika Serikat memberitahukan keputusan banding. Amerika Serikat menginformasikan untuk mengajukan banding pada 5 Januari 2012 dan pada 29 Februari 2012 Appellate Body menyatakan tidak bisa mengedarkan laporan dalam 60 hari karena diperlukan waktu lebih lama untuk penyelesaian dan penerjemahan laporan, dan estimasi sirkulasi tidak lebih dari 4 April 2012. Pada tanggal tersebut, laporan Appellate Body diedarkan kepada negara-negara anggota.

WTO kembali memenangkan rokok kretek Indonesia di tingkat banding. Appellate Body memperkuat keputusan Panel bahwa Amerika Serikat telah melanggar prinsip non-diskriminasi dan mengeluarkan kebijakan yang tidak konsisten. Appellate Body juga menemukan bahwa kebijakan Amerika Serikat

16 WHO, Partial Guidelines for Implementation of Articles 9 and 10 of the WHO Framework Convention on Tobacco Control: Regulation of the Contents of Tobacco Products and of Tobacco Product Disclosures, http://www.who.int/fctc/guidelines/adopted/article_9and10/en/, diakses pada 3 April 2017. 
melanggar Pasal 2.12 TBTA, karena tidak memberikan waktu yang cukup antara sosialisasi kebijakan dan waktu penetapan kebijakan. Penerapan kebijakan tersebut juga melanggar Pasal 2.9.2 TBTA yang mengharuskan dilakukannya notifikasi kepada semua anggota melalui Sekretariat WTO. DSB telah mengadopsi rekomendasi dan keputusan untuk meminta Pemerintah Amerika Serikat agar segera mengimplementasikannya sesuai TBTA.

Hingga kurun waktu selama 15 bulan hingga 24 Juli 2013, Amerika Serikat belum melaksanakan keputusan DSB. Indonesia terus mendesak agar Amerika Serikat melaksanakan keputusan WTO tersebut karena akibat ketidakpatuhan Amerika Serikat, Indonesia menanggung kerugian yang diperkirakan lebih dari US \$160 juta dalam kurun waktu tiga tahun sejak Amerika Serikat memberlakukan Undang-Undang yang dipersengketakan. Maka dari itu Indonesia berhak mendapatkan kompensasi. WTO bahkan mengizinkan Indonesia melakukan retaliasi. Pada 12 Agustus 2013, Indonesia meminta otorisasi DSB untuk melakukan penangguhan konsesi dan kewajiban-kewajiban lainnya di bawah Pasal 22.2 DSU, dan pada 22 Agustus 2013 ditolak Amerika Serikat dan membawa kasus kepada arbitrase, disetujui DSB pada pertemuan 23 Agustus 2013. Arbitrase tersebut untuk menentukan nilai kompensasi berdasarkan kerugian yang diderita Indonesia berdasarkan ketentuan DSU. Kemudian pada 23 Juni 2014, Indonesia dan Amerika Serikat meminta Arbitrator untuk menunda pengedaran award karena alasan-alasan tertentu, dan pada 24 Juni 2014 Arbitrator melaporkan kepada DSB telah menyetujui permintaan para pihak. Pada 3 Oktober 2014 Indonesia dan Amerika Serikat menginformasikan kepada DSB bahwa telah dicapai solusi yang disepakati bersama. Indonesia menarik permohonan penangguhan konsesi dan kewajiban-kewajiban lainnya, dan Amerika Serikat juga menarik keberatannya atas permohonan tersebut. Pada 8 Oktober 2014, Ketua Arbitrator menginformasikan kepada DSB bahwa tidak lagi diperlukan untuk memutus kasus tersebut dan menganggap tugasnya telah selesai.

Indonesia dan Amerika Serikat mengakhiri kasus dengan Memorandum of Understanding yang meski tetap melarang rokok kretek, tetapi memberi keuntungan lain bagi Indonesia. Amerika Serikat akan memberikan tambahan 
fasilitas generalized system of preference selama lima tahun atau akses khusus yang diberikan bagi produk industri dan pertanian dari negara berkembang untuk masuk ke negara maju, mempertimbangkan ekspor lain dari Indonesia, tidak mengadukan kebijakan larangan atau pembatasan ekspor bahan mineral yang diterapkan Indonesia, tidak melarang akses pasar produk cigars dan cigarrillos (sejenis cerutu) buatan Indonesia ke pasar Amerika Serikat, dan membantu Indonesia dalam penegakkan Hak Kekayaan Intelektual Indonesia. Dengan diakhirinya kasus ini, kedua negara semakin memperkuat kerjasama perdagangan dan investasi internasional dalam Indonesia-US Trade and Investment Framework Agreement yang berdampak positif bagi hubungan jangka panjang kedua negara.

\section{Posisi, Tantangan, dan Prospek Bagi Indonesia}

Pada kasus Indonesia - Autos, Indonesia didesak negara-negara maju yang memandang Indonesia sebagai lahan subur perdagangan otomotif yang jika dibatasi dengan program mobil nasional Indonesia akan sangat merugikan negara-negara maju tersebut. Meski program mobil nasional yang dicanangkan Indonesia adalah program yang sangat positif untuk industri mobil nasional, sayangnya Indonesia masih lemah dalam hal infrastruktur dan produksi mandiri dengan menggunakan produk Korea Selatan, sehingga menimbulkan kecaman dari negara-negara lainnya dan berakibat pada praktek yang diskriminatif. Program tersebut juga menunjukkan tindakan proteksi Indonesia terhadap pasar dalam negeri yang berdampak negatif bagi negara-negara lain dalam ranah perdagangan internasional. Negara-negara Eropa menyatakan subsidi yang diberikan pemerintah Indonesia dalam program mobil nasional ini menimbulkan kerugian serius bagi produk sejenis dari Eropa.

Sementara permasalahan yang dihadapi Indonesia sebagai salah satu complainant dalam kasus US - Offset Act adalah Amerika Serikat yang tidak benarbenar menunjukkan kepatuhan terhadap rekomendasi-rekomendasi DSB. Dalam kasus ini Indonesia aktif memperjuangkan kepentingan ekonomi bersama meski berhadapan dengan negara maju sekelas Amerika Serikat. Proses penyelesaian sengketa ini berjalan sesuai tahap dalam DSU, hanya saja melebihi batas waktu 
yang ditetapkan karena proses persidangan diakibatkan kompleksitas kasus dan pengimplementasian rekomendasi DSB oleh Amerika Serikat jauh melampaui waktu yang ditentukan.

Dalam kasus Korea-Certain Paper, mengingat sistem penyelesaian sengketa adalah government-to-government, perusahaan-perusahaan Indonesia yang dirugikan menginisiasi penyelesaian sengketa melalui pemerintah Indonesia. Pemerintah menyadari bahwa kepentingan dari perusahaan-perusahaan tersebut adalah kepentingan ekonomi Indonesia juga sehingga perlu difasilitasi. Beberapa klaim Indonesia ditolak karena tidak bisa membuktikan secara prima facie, namun Indonesia tetap memenangkan kasus tersebut. Hanya saja, sama seperti dalam kasus US-Offset Act, Korea Selatan juga menunda hampir tiga tahun sebelum akhirnya melaksanakan rekomendasi dan keputusan DSB. Pada tahun 2010, Sinar Mas bahkan sempat meminta tindakan retaliasi karena ketidakpatuhan Korea Selatan terhadap keputusan yang ada. Kasus ini kemudian dihentikan pada Oktober 2010, karena KTC telah secara resmi mengakhiri pengenaan bea masuk anti-dumping terhadap produk kertas berupa uncoated writing dan printing paper dari Indonesia. KTC juga menghentikan pengenaan bea masuk anti-dumping terhadap produk dari China.

Selanjutnya, kasus keempat yakni US-Clove Cigarettes dimana Indonesia sebagai complainant sendiri merupakan kasus unik, bahkan diberi penghargaan oleh majalah hukum The American Lawyer sebagai 'Global Dispute of the Year'.17 Kemenangan Indonesia dalam persidangan Panel dan banding atas Amerika Serikat yang adalah negara maju adalah pencapaian besar. Ketika Amerika Serikat menunda pelaksanaan rekomendasi, Indonesia bersiap untuk melakukan retaliasi, namun selanjutnya tetap bersedia menarik permohonan retaliasi terhadap Amerika Serikat tersebut setelah melakukan negosiasi merupakan bentuk penghargaan Indonesia terhadap hubungan bilateral dengan Amerika Serikat.

\footnotetext{
17 Tempo, Menang Sengketa WTO, Indonesia Dapat Penghargaan, http://bisnis.tempo.co/read/news/2013/09/25/092516518/menang-sengketa-wto-indonesiadapat-penghargaan diakses pada 3 April 2017.
} 
Meninjau empat kasus tersebut, Indonesia telah cukup menunjukkan eksistensi dan memperjuangkan kepentingan nasional meski harus dihadapkan dengan negara-negara maju. Setidaknya ada dua permasalahan yang dihadapi Indonesia dalam memperjuangkan kepentingannya, yang pertama lemahnya pembuktian untuk mendukung sanggahan, dan yang kedua ketidakpatuhan respondent terhadap keputusan DSB sebagai hasil adopsi laporan Panel dan Appellate Body, ataupun award Arbitrase yang menjelaskan tenggat waktu pelaksanaan rekomendasi.

Permasalahan pertama dapat diselesaikan dengan memperkuat standing Indonesia melalui peningkatan sumber daya manusia dengan pemahaman hukum, politik, dan ekonomi yang memadai, serta pengumpulan bukti dan informasi yang dapat mendukung gugatan atau sanggahan secara komprehensif. Permasalahan ini lebih bersifat teknis, sehingga dapat diusahakan oleh pemerintah melalui kementerian terkait dan firma hukum yang ditugaskan. Selain itu, untuk mendukung usaha tersebut sebagai negara berkembang Indonesia dapat memanfaatkan klausula-klausula dalam DSU yaitu special dispute settlement rules and procedures dan Advisory Centre on WTO Law (ACWL).18 ACWL telah dibentuk sejak 1999 untuk membantu negara-negara berkembang mendapatkan legal advice dalam hukum WTO dan perekonomian yang mengalami transisi, diberikan dalam bentuk advisory opinion atas pertanyaan hukum, analisis situasi perdagangan, atau legal advice selama proses persidangan. ${ }^{19}$ ACWL dapat menjadi sarana untuk memahami sistem penyelesaian sengketa WTO hingga kepentingannya dapat diperjuangkan secara efektif. ${ }^{20}$ Sistem penyelesaian sengketa dalam DSB pada dasarnya bukanlah sistem yang memihak, tetapi untuk bisa memenangkan kasus perlu pemahaman hukum dan ekonomi yang mendalam untuk memperkuat posisi penuntut ataupun tertuntut.

\footnotetext{
18 Bernard Hoekman, et.al. (eds.), Development, Trade and the WTO: A Handbook, The World Bank, Washington, 2002, hlm., 75. 19 Id.

${ }^{20}$ Gregory Shaffer, Assessing the Advisory Centre on WTO Law from a Broader Governance Perspective, Minnesota Legal Studies Research Paper No. 11-46, 29 November 2011.
} 
Permasalahan kedua yakni non-compliance adalah hal yang berbeda, dimana meski sudah ada ketentuan dalam DSU mengenai pengimplementasian rekomendasi dan keputusan, ada pula faktor-faktor lain seperti faktor ekonomi, politik, dan pandangan terhadap posisi negara lawan sengketa, sementara di sisi lain kepatuhan negara-negara sangat berdampak terhadap efektivitas sistem penyelesaian sengketa WTO. ${ }^{21}$ Ketidakpatuhan sebagai faktor kesengajaan dari pihak yang bertanggungjawab untuk segera melaksanakan tuntutan dalam waktu yang ditetapkan sangat merugikan negara yang menuntut, karena kegiatan perekonomian terus berjalan meski kewajiban belum dilaksanakan. Akibat noncompliance Korea Selatan, pengusaha Indonesia merugi dan mengakibatkan ketidakstabilan perekonomian nasional Indonesia. Indonesia sendiri menunjukkan kepatuhan dengan mengubah Undang-Undang mengenai mobil nasional sebelum tenggat waktu berakhir.

DSU menyatakan retaliasi diperbolehkan saat berhadapan dengan noncompliance pihak yang dituntut, tetapi tindakan ini tidak dapat dilakukan secara sembarangan. Retaliasi dalam WTO harus disahkan WTO secara multilateral, dan retaliasi harus setara dan sesuai dengan kerugian akibat pelanggaran yang dipersengketakan. Pada prakteknya, retaliasi sangat rumit dan hanya negara maju seperti Amerika Serikat dan Uni Eropa yang berhasil, ${ }^{22}$ karena retaliasi hanya efektif bila diajukan negara dengan pasar domestik besar sehingga mampu memberikan kerugian ekonomi atau politik bagi pihak lain demi meningkatkan kepatuhan. ${ }^{23}$ Ketika Indonesia mengancam melakukan retaliasi terhadap Amerika Serikat untuk ekspor rokok kretek, ancaman diindahkan karena Indonesia memiliki pasar domestik yang besar dan akan merugikan Amerika Serikat, tetapi ancaman retaliasi Antigua, negara kecil dengan jumlah penduduk delapan puluh ribu jiwa, untuk menghentikan hubungan perdagangan dengan Amerika Serikat yang hanya sekitar 0.02 persen dari total keseluruhan ekspor Amerika Serikat,

${ }^{21}$ William J. Davey, Implementation in WTO Dispute Settlement: An Introduction to the Problems and Possible Solutions, The Research Institute of Economy, Trade and Industry - Discussion Paper Series, 1, 2005.

22 Chad P. Bown, et.al. (eds.), The Law, Economics and Politics of Retaliation in WTO Dispute Settlement, Cambridge University Press, Cambridge, 2010, hlm., 235.

${ }^{23}$ Id., hlm., 321. 
tidak akan berdampak pada ekonomi Amerika Serikat karena negara tersebut dapat mengalihkan volume perdagangan itu di tempat lain. ${ }^{24}$ Untuk menanggulangi ketidakpatuhan, Indonesia sendiri tidak bisa terus bergantung pada tindakan retaliasi, yang pada dasarnya tidak menguntungkan bagi pasar domestik negara berkembang.

Dengan alasan-alasan tersebut, maka penulis berpandangan bahwa pemaksaan kepatuhan harus dilakukan dari sistem WTO sendiri. Alternatif pertama adalah dengan mengubah ketentuan Pasal 21 DSU mengenai Surveillance of Implementation of Recommendations and Rulings, diperluas menjadi Determination of Compliance. ${ }^{25}$ Proposal ini telah diajukan oleh pemerintah Jepang bersama negara-negara lain. ${ }^{26}$ Dalam Pasal 21.5 DSU diatur mengenai pembentukan Panel (umumnya disebut Compliance Panel), persidangan untuk melihat apakah tergugat telah melaksanakan rekomendasi DSB dan juga apakah langkah-langkah yang diambil sesuai dengan ketentuan WTO.27 Untuk putusan Compliance Panel dapat diajukan banding. Namun dalam Proposal Determination of Compliance, DSU tidak hanya mengatur mengenai pengawasan atas implementasi, tetapi juga tindakan yang perlu dilakukan agar negara-negara benar-benar melaksanakan rekomendasi dan keputusan DSB. Dalam proposal ini, pembentukan Compliance Panel dapat dimohonkan penuntut (a) kapanpun setelah negara yang dituntut menyatakan tidak memperlukan waktu tambahan untuk mengimplementasi, (b) kapanpun setelah negara yang dituntut menyatakan telah menginformasikan implementasinya, atau (c) sepuluh hari sebelum waktu yang wajar untuk melakukan rekomendasi berakhir. Pembentukan Compliance Panel dalam proposal ini tidak memerlukan konsultasi dari pihak yang

\footnotetext{
${ }^{24}$ WTO, Recourse by Antigua and Barbuda to Article 22.2 of the DSU, United States-Measures Affecting the Cross-Border Supply of Gambling and Betting Services (US-Gambling), WT/DS285/22, 22 June 2007, paragraph 3.

${ }^{25}$ Supra no 18, hlm., 77.

${ }^{26}$ WTO, Proposed Amendment of the Dispute Settlement Understanding: submitted by the government of Japan on behalf of co-sponsors Canada, Costa Rica, the Czech Republic, Ecuador, the European Communities (and its member states), Hungary, Japan, Korea, New Zealand, Norway, Peru, Slovenia, Switzerland, Thailand, and Venezuela, WT/MIN(99)8, 22 November 1999.

${ }^{27}$ Appellate Body Report, Canada-Measures Affecting the Export of Civilian Aircraft, WT/DS70/AB/R, adopted 20 August 1999, DSR 1999:IV.
} 
bersengketa, dan terhadap laporan Compliance Panel tidak bisa dilakukan banding. Jika Compliance Panel mendapati bahwa pihak yang bersangkutan gagal melaksanakan kepatuhan dalam jangka waktu yang ditentukan, penuntut dapat meminta otorisasi DSB untuk penangguhan konsesi atau kewajiban lainnya.

Langkah selanjutnya yang bisa dilakukan terhadap sistem penyelesaian sengketa WTO adalah perluasan Pasal 22 DSU terkait kompensasi dan penangguhan konsesi dimana istilah kompensasi tidak dielaborasi. Pakistan mengajukan proposal agar kompensasi diatur dalam bentuk finansial yang dibayarkan respondent kepada complainant untuk kerugian yang diderita akibat pelanggaran negara yang dituntut. ${ }^{28}$ Selain itu kompensasi juga bisa diajukan dalam bentuk non-finansial, yakni penambahan akses pasar kepada pihak yang dirugikan. ${ }^{29}$ Pelanggaran terhadap peraturan-peraturan WTO pun perlu dianggap sebagai masalah kolektif, sehingga membutuhkan respon kolektif dari pihak-pihak yang dirugikan. Permasalahannya, peraturan-peraturan WTO sekarang ini dipandang hanya mengatur secara bilateral sehingga muncul urgensi agar peraturan WTO benar-benar dipandang sebagai produk multilateral yang memberikan peraturan-peraturan hukum sebagai produk publik dan penegakannya harus dilakukan secara kolektif. ${ }^{30}$ Retaliasi dan kompensasi dapat meningkatkan kepatuhan, dan kompensasi atas cidera kolektif diberikan secara kolektif kepada seluruh anggota, tidak hanya satu-dua negara yang membawa kasus tersebut dalam persidangan. ${ }^{31}$ Hal ini diharapkan akan meningkatkan kepatuhan negara-negara atas rekomendasi dan keputusan DSB, agar negara yang menuntut tidak semakin dirugikan dan negara yang dituntut pun menjalankan kewajibannya sesuai waktu yang ditentukan.

\footnotetext{
${ }^{28}$ WTO, Communication from Pakistan to the General Council, WT/GC/W/162, 1 April 1999.

${ }^{29}$ Joost Pauwelyn, Enforcement and Countermeasures in the WTO: Rules Are Rules-Toward a More Collective Approach, 94 American Journal of International Law, 2000, hlm., 307-343.

${ }^{30}$ Id., hlm., 340; lihat juga Joost Pauwelyn, A Typology of Multilateral Treaty Obligations: Are WTO Obligations Bilateral or Collective in Nature?, 14 European Journal of International Law, 2003, hlm., 907-951.

31 Supra no. 29, hlm., 343.
} 


\section{Penutup}

Usaha untuk melindungi kepentingan nasional negara perlu diupayakan semaksimal mungkin, mengingat perekonomian negara sangat berdampak pada kemakmuran rakyat. Pembangunan nasional Indonesia sendiri tujuan utamanya adalah demi tercapainya kesejahteraan rakyat. Di sisi lain, Indonesia pun harus mengusahakan hubungan kerja sama yang baik dengan negara lain karena kebergantungan satu negara kepada negara yang lain adalah keniscayaan. Meski demikian, mengetahui bahwa sengketa tidak bisa terhindarkan, WTO telah menyediakan mekanisme agar setiap sengketa yang dihadapi diselesaikan secara damai. Namun ada saja celah yang menghambat efektivitas sistem penyelesaian sengketa tersebut.

Dengan bertitik-tolak pada permasalahan yang dihadapi Indonesia yaitu lemahnya argumen dan bukti yang mendukung gugatan atau sanggahan, dan ketidakpatuhan negara lain dalam melaksanakan rekomendasi DSB sehingga menimbulkan kerugian bagi perekonomian nasional Indonesia, penulis mengajukan beberapa saran yang diharapkan dapat membantu. Capacity-building harus dilakukan Indonesia dari segi hukum, ekonomi, dan politik, sehingga meningkatkan kuatnya argumen dan pengumpulan bukti. Sedangkan untuk masalah ketidakpatuhan, yang mana hal ini sangat dipengaruhi banyak faktor di luar kekuasaan negara complainant, maka yang dapat dilakukan adalah reformasi DSU dalam hal pengawasan kepatuhan dan kompensasi serta penangguhan konsesi. Proposal peningkatan kapasitas Compliance Panel dan pengaturan spesifik mengenai pemberian kompensasi dalam bentuk finansial ataupun akses pasar diharapkan dapat mendorong negara-negara dalam melaksanakan rekomendasi dalam waktu yang telah disepakati. Proposal adanya pengaturan pemberian kompensasi kolektif juga dapat menjadi cambuk kepatuhan. Kepatuhan sendiri memiliki dampak positif, tidak hanya kepada negara complainant tetapi juga kepada negara respondent yang tidak perlu membayar kompensasi. 


\section{Daftar Pustaka}

\section{Dokumen WTO:}

Appellate Body Report, Canada - Measures Affecting the Export of Civilian Aircraft, WT/DS70/AB/R, adopted 20 August 1999, DSR 1999:IV.

Panel Report, Indonesia - Certain Measures Affecting the Automobile Industry, WT/DS54/R, WT/DS55/R, WT/DS59/R, WT/DS64/R and Corr.1 and Corr.2, adopted 23 July 1998, and Corr.3 and Corr.4, DSR 1998:VI.

Panel Report, Korea - AntiDumping Duties on Imports of Certain Paper from Indonesia, WT/DS312/R, adopted 28 November 2005, DSR 2005:XXII, hlm. 10637; Panel Report, Korea - AntiDumping Duties on Imports of Certain Paper from Indonesia - Recourse to Article 21.5 of the DSU by Indonesia, WT/DS312/RW, adopted 22 October 2007, DSR 2007:VIII.

Panel Report, United States - Continued Dumping and Subsidy Offset Act of 2000, WT/DS217/R, WT/DS234/R, adopted 27 January 2003, as modified by Appellate Body Report WT/DS217/AB/R, WT/DS234/AB/R, DSR 2003:II.

Panel Report, United States - Measures Affecting the Production and Sale of Clove Cigarettes, WT/DS406/R, adopted 24 April 2012, as modified by Appellate Body Report WT/DS406/AB/R, DSR 2012: XI.

WTO, Article II; Understanding on Rules and Procedures Governing the Settlement of Disputes, 1994, 1869 U.N.T.S. 401,

WTO, Communication from Pakistan to the General Council, WT/GC/W/162, 1 April 1999.

WTO, Proposed Amendment of the Dispute Settlement Understanding: submitted by the government of Japan on behalf of co-sponsors Canada, Costa Rica, the Czech Republic, Ecuador, the European Communities (and its member states), Hungary, Japan, Korea, New Zealand, Norway, Peru, Slovenia, Switzerland, Thailand, and Venezuela, WT/MIN(99)8, 22 November 1999.

WTO, Recourse by Antigua and Barbuda to Article 22.2 of the DSU, United States Measures Affecting the Cross-Border Supply of Gambling and Betting Services (US - Gambling), WT/DS285/22, 22 June 2007.

\section{Buku:}

Bernard Hoekman, et.al. (eds.), Development, Trade and the WTO: A Handbook, The World Bank, Washington, 2002.

Chad P. Bown, et.al. (eds.), The Law, Economics and Politics of Retaliation in WTO Dispute Settlement, Cambridge University Press, Cambridge, 2010.

G. Sampson, (ed.), The Role of the World Trade Organization in Global Governance, United Nations University Press, Tokyo, 2001.

Peter Malanczuk, Akehurst's Modern Introduction to International Law, Seventh Revised Edition, Routledge, New York, 1997.

Peter Van den Bossche, The Law and Policy of the World Trade Organization: Text, Cases and Materials, Cambridge University Press, Cambridge, 2005.

World Trade Organization, A Handbook on the WTO Dispute Settlement System, Cambridge University Press, Cambridge, 2004. 


\section{Jurnal dan Artikel:}

Freddy Josep Pelawi, Penyelesaian Sengketa WTO dan Indonesia, Direktorat Jenderal Kerjasama Perdagangan Internasional, Buletin KPI Edisi 44, 2007.

Gregory Shaffer, Assessing the Advisory Centre on WTO Law from a Broader Governance Perspective, Minnesota Legal Studies Research Paper No. 11-46, 29 November 2011.

Joost Pauwelyn, A Typology of Multilateral Treaty Obligations: Are WTO Obligations Bilateral or Collective in Nature?, 14 European Journal of International Law, 2003.

Enforcement and Countermeasures in the WTO: Rules Are RulesToward a More Collective Approach, 94 American Journal of International Law, 2000.

William J. Davey, Implementation in WTO Dispute Settlement: An Introduction to the Problems and Possible Solutions, The Research Institute of Economy, Trade and Industry-Discussion Paper Series, 1, 2005.

World Trade Organization, WTO Dispute Settlement: One Page Case-Summaries 1995-2014 (2015).

\section{Lain-lain:}

Tempo, Indonesia Menangkan Sengketa Melawan Korea di WTO, http://bisnis.tempo.co/read/news/2005/10/31/05668752/IndonesiaMenangkan-Sengketa-Melawan-Korea-di-WTO

Tempo, Menang Sengketa WTO, Indonesia Dapat Penghargaan, http://bisnis.tempo.co/read/news/2013/09/25/092516518/menangsengketa-wto-indonesia-dapat-penghargaan

Tempo, Penghentian Kasus Dumping Kertas Belum Direspons Pengusaha Korea, http://bisnis.tempo.co/read/news/2010/10/25/090286990/penghentian -kasus-dumping-kertas-belum-direspons-pengusaha-korea

WHO, Partial Guidelines for Implementation of Articles 9 and 10 of the WHO Framework Convention on Tobacco Control: Regulation of the Contents of Tobacco Products and of Tobacco Product Disclosures, http://www.who.int/fctc/guidelines/adopted/article_9and10/en/ 